\title{
Utilization of Water Treatment Plant Sludge and Coal Fly Ash in Brick Manufacturing
}

\author{
Denise Alves Fungaro*, Mauro Valério da Silva \\ Instituto de Pesquisas Energéticas e Nucleares, IPEN-CNEN/SP, São Paulo, SP, Brasil \\ *Corresponding author: dfungaro@ipen.br
}

Received August 02, 2014; Revised October 09, 2014; Accepted October 12, 2014

\begin{abstract}
Sludge from a treatment water Brazilian plant station is, frequently, disposed and launched directly in the water bodies, causing a negative impact in the environment. Also, fly ash is produced by burning of coal in coalfired power stations and is the industrial solid waste most generated in southern Brazil: approximately 4 million tons/y. An efficient disposal of coal fly ash is an issue due to its massive volume and harmful risks to the environment. The main purpose of this study was to evaluate the technical possibilities of incorporating cyclone fly ash (CFA) and sludge from a waste water treatment plant (SWTP) in the production of ecological bricks. The wastes were analyzed for physico-chemical, mineralogical and morphological properties. Various mixtures were prepared by incorporating these industrial wastes in brick production. The effects of wastes incorporation on physical properties such as compressive strength and water absorption have been determined. The best result, in terms of compression strength and water absorption, was reached by the series of bricks produced with $60 \%$ soil, $12 \%$ cement, $8 \%$ coal fly ash and $20 \%$ SWTP by weight. The results showed that SWTP and CFA presented a potential to be used as waste additives in the production of soil-cement bricks.
\end{abstract}

Keywords: ecological brick, waterworks sludge, coal fly ash, soil-cement brick, soil-lime brick

Cite This Article: Denise Alves Fungaro, and Mauro Valério da Silva, "Utilization of Water Treatment Plant Sludge and Coal Fly Ash in Brick Manufacturing." American Journal of Environmental Protection, vol. 2, no. 5 (2014): 83-88. doi: 10.12691/env-2-5-2.

\section{Introduction}

Water treatment plants produce large quantities of sludge as a result of treatment processes of raw water such as coagulation, flocculation and filtration [1,2,3,4]. The by-product from the purification process is a huge amount of waste in the form of sludge called water treatment residual or waterworks sludge, which after drying is considered to be a non-biodegradable waste material.

The sludge composition in water treatment plants is mainly determined by the geology, hydrology of the river basin, human activities in catchments and chemicals used in a purification process. Consequently sludge produced from water purification processes may contain high concentrations of those chemical removed by the purification processes.

Aluminium sulphate is the most widely used coagulant in drinking water treatment. Some researchers have linked aluminums' contributory influence to occurrence of Alzheimer, children mental retardation, and the common effects of heavy metals accumulation [5,6].

The common practice by most water treatment plants is the disposal of sludge to the nearest watercourse around the treatment plant without prior treatment. However, the laws in Brazil are demanding a change in this behavior, and thus proper management of the sludge becomes inevitable.
The mineralogical composition of sludge from a water treatment plant is clay, silt, and sand [7]. This means that the waterworks waste has the potential to be used as a possible new additive to clay-based products $[4,7,8]$. The reuse of waterworks waste for obtaining soil-cement bricks has also been recently suggested $[9,10,11]$.

Similarly, the disposal of the large amount of fly ash generated from combustion of coal is also a major concern as it possesses health hazards and severe implications for the environment. The main drawback of coal-fired power plants in Brazil is the high production of ash. Fly ash represents about $65-85 \%$ of coal-ash produced by thermal power plants, while bottom ash accounts for 15-35\% wt $[12,13,14]$.

The fly ash is a fine-grained, powdery particulate material that is carried off in the flue gas and usually collected from the flue gas by means of electrostatic precipitators, baghouses, or mechanical collection devices such as cyclones [15].

Fly ash from a baghouse filter produced in the Brazilian power plant is mostly recycled as a cement raw material to be used in civil engineering materials. However, cyclone ash does not find at present time a commercial application; rather, it is usually stored in an abandoned surface mine or dumped in landfills in the vicinity of the power plant.

The utilization of fly ash in construction, as a low-cost adsorbent for the removal of organic compounds, flue gas and metals, light weight aggregate, mine back fill, road sub-base, and zeolite synthesis has been widely examined 
[11-16]. However, there is a perpetual request for new applications of fly ash since the amount of this coal waste released by thermal power plants has been increasing throughout the world.

The purpose of this study was to investigate the characteristics and possible utilization of waterworks sludge and coal fly ash in the production of bricks. The suitable conditions of using dried sludge and coal fly ash in producing bricks under the criteria of Brazilians Standards were investigated. The influence of wastes proportion in the raw materials in relation to the brick was also examined.

\section{Experimental}

\subsection{Materials}

All the reagents used for experimental studies were of analytical grade. The samples of coal fly ash from a cyclone filter (CFA) were obtained from a coal-fired power plant located at Figueira County, in Paraná State, Brazil. The used sludge from a water treatment plant (SWTP) used was collected from a waterworks located in Terra Preta County in São Paulo State, Brazil. Commercial Portland cement (type CP-III-32-SP) and sandy soil were used.

\subsection{Production of Bricks}

The methodology consisted in identifying the most appropriate proportion of fly ash, SWTP, soil, cement or lime for the manufacture of bricks. The procedure for sample preparation followed the NBR10832 [17] and NBR 10834 standard [18].

Five fly ash, sludge, soil, cement or lime mixtures with different mass ratios were prepared, besides a bricks series without addition of wastes and lime (the control pattern) are presented in Table 1 . The dimensions of the bricks were $20.0 \mathrm{~cm}$ wide, $4.8 \mathrm{~cm}$ height and $10.1 \mathrm{~cm}$ width.

Technical evaluation of the bricks was performed according to Brazilian norms. Compressive strength and absorption tests were performed on the bricks according the NBR10836 standard after the curing time of 28 day [19]. From each series, tests were done to determine the compression resistance and water absorption tests (on 3 bricks).

Table 1. Materials used in the preparation of bricks

\begin{tabular}{|c|c|c|c|c|c|}
\hline Group & \multicolumn{5}{|c|}{ Proportion of materials (mass \%) } \\
\hline & Soil & Cement & CFA & SWTP & Lime \\
\hline BW-0 & 85 & 15 & - & - & - \\
\hline BW-1 & - & - & 10 & 90 & - \\
\hline BW-2 & 45 & 5 & 5 & 45 & - \\
\hline BW-3 & 60 & 10 & 10 & 20 & - \\
\hline BW-4 & 60 & 12 & 8 & 20 & - \\
\hline BW-5 & 60 & - & 13 & 20 & 7 \\
\hline BW-6 & 65 & - & 7 & 20 & 13 \\
\hline
\end{tabular}

\subsection{Characterization of Materials}

The chemical compositions of materials were analyzed by energy dispersive XRF (X-ray fluorescence spectrometry) using (RX Axios Advanced, PANalytical, Phillips spectrometer). Phase and crystallinity were confirmed by powder XRD (Rigaku Multiflex) with nickel filter $\mathrm{CuK} \alpha$ radiation $(\lambda=1.54060 \AA)$ scanning from 5 to $80^{\circ}$ at a rate of $1^{\circ} / \mathrm{min}$ with current $40 \mathrm{kV}$ and $20 \mathrm{~mA}$. The Fourier transform infrared spectroscopy (FTIR), spectra were recorded on Nexus 670 Thermo Nicolet using $\mathrm{KBr}$ pellet method. Scanning Electron micrograph was obtained by using XL-30 Philips scanning electron microscope (SEM). The particle size of the materials was measured using a laser based particle size analyzer, namely a Malvern MSS Mastersizer 2000 Ver. 5.54. The real density and the specific surface area of fly ashes and zeolite samples were determined by a helium picnometer (Micromeritcs Instrument Corporation - Accupyc 1330) and by a BET Surface Area Analyser (Quantachrome Nova - 1200), respectively. Prior to determination of the specific surface area, samples were heated at $423.15 \mathrm{~K}$ for $12 \mathrm{~h}$ to remove volatiles and moisture in a degasser (Nova 1000 Degasser). The BET surface areas were obtained by applying the BET equation to the nitrogen adsorption data. Thermogravimetric and differential thermogravimetric analyses (TG/DTG) were carried out using a Mettler Toledo STAR SW 9.30 thermogravimetric analyzer with heating rate of $10{ }^{\circ} \mathrm{C}$ min-1 between $25-1400{ }^{\circ} \mathrm{C}$, under nitrogen flow rate of about $50 \mathrm{ml}$ min-1. Other relevant characteristics of SWTP such as organic matter content, $\mathrm{pH}$, cation exchange capacity, the loss on ignition and total solids content, fixed solids, volatile solids were also determined. Physicochemical characterizations of fly ash are reported in previous study [20].

\section{Results and Discussion}

\subsection{Characterization of SWTP}

The X-ray diffraction pattern of the waterworks waste sample is shown in Figure 1. The sample exhibited peaks that are characteristics of kaolinite $\left(\mathrm{Al}_{2} \mathrm{Si}_{2} \mathrm{O}_{3}(\mathrm{OH})_{4}\right)$, quartz $\left(\mathrm{SiO}_{2}\right)$, goethite $(\mathrm{FeO}(\mathrm{OH}))$, and muscovite $\left(\mathrm{KAl}_{3} \mathrm{Si}_{3} \mathrm{O}_{10}(\mathrm{OH})_{2}\right)$, also known as mica, with predominance of kaolinite and quartz.

Table 2 presents the chemical composition of the waterworks waste sample. Although the properties of the sludge samples are highly variable and dependent on both the type of the raw water and the chemical composition of coagulant [21], it can be seen from Table 2 that aluminum is the dominant component in the dewatered alum sludge with $\sim 39 \%$ in mass expressed as $\mathrm{Al}_{2} \mathrm{O}_{3}$. The other principal chemical components were $\mathrm{SiO}_{2}$ and $\mathrm{Fe}_{2} \mathrm{O}_{3}$.

Table 2. Chemical composition of the waterworks waste

\begin{tabular}{|c|c|}
\hline Oxides & wt\% \\
\hline $\mathrm{Al}_{2} \mathrm{O}_{3}$ & 39.1 \\
\hline $\mathrm{SiO}_{2}$ & 30.2 \\
\hline $\mathrm{Fe}_{2} \mathrm{O}_{3}$ & 25.8 \\
\hline $\mathrm{K}_{2} \mathrm{O}$ & 1.4 \\
\hline $\mathrm{TiO}_{2}$ & 1.4 \\
\hline $\mathrm{MgO}$ & 0.6 \\
\hline $\mathrm{SO}_{3}$ & 0.6 \\
\hline $\mathrm{P}_{2} \mathrm{O}_{5}$ & 0.3 \\
\hline $\mathrm{MnO}$ & 0.3 \\
\hline $\mathrm{CaO}$ & 0.2 \\
\hline others & $\leq 0.09$ \\
\hline
\end{tabular}


This result is consistent with the X-ray diffraction data (Figure 1). The alumina does not occur in its free form in the waterworks waste sample, being bounded to the clay minerals (kaolinite and muscovite). The quartz is present in the structure of clay minerals and free silica particles. The iron oxide is present in the structure of the goethite. The contents of alkaline oxide $\left(\mathrm{K}_{2} \mathrm{O}\right), \mathrm{TiO}_{2}$, alkaline earth ( $\mathrm{CaO}$ and $\mathrm{MgO}$ ), $\mathrm{SO}_{3}$ and $\mathrm{P}_{2} \mathrm{O}_{5}$ are between $0.2-1.4 \%$.

The presence of these elements is attributed to the use of aluminium sulfate as coagulants in water treatment plants and due to the composition of the water, which contains suspended materials, such as sand and clay materials.

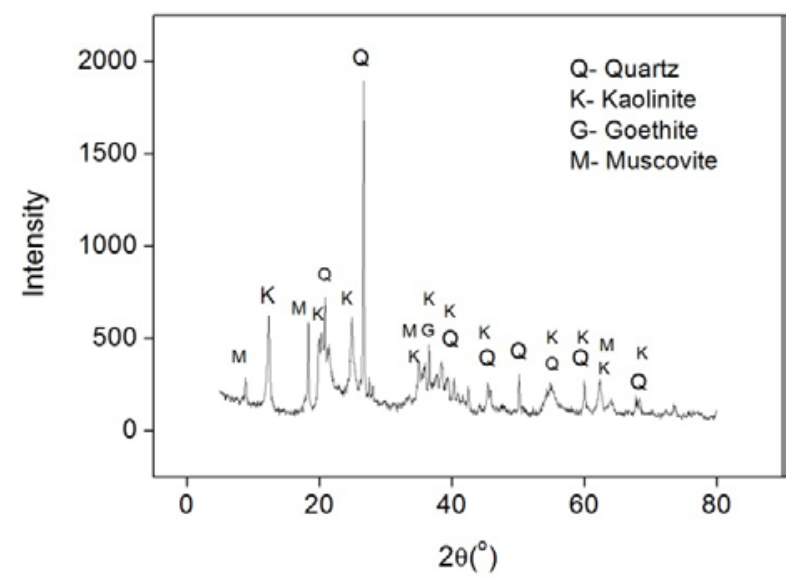

Figure 1. X-ray Diffraction pattern of the waterworks waste sample

Some important physicochemical characteristics of waterworks waste sample are shown in Table 3. Usually, the moisture content of the waterworks sludge is at least $80 \%$. Loss on ignition (LOI) implied in high weight loss of about 52.0 wt. \%, is mainly attributed to the presence of clay minerals, hydroxides, and organic matter in the waste sample [22].

Table 3. Chemical composition of the waterworks waste

\begin{tabular}{|l|l|}
\hline Characteristics & Obtained Values \\
\hline Humidity (\%) & 85.0 \\
\hline Loss og ignition (\%) & 52.0 \\
\hline pH in water & 5.57 \\
\hline CEC ( meq 100 g-1) & 9.34 \\
\hline Organic matter content & 24.3 \\
\hline Apparent density (g cm-3) & 1.75 \\
\hline True density (g cm-3) & 2.27 \\
\hline Specific surface area (m2 g-1) & 106.9 \\
\hline Total solids (\%) & 9.85 \\
\hline Fixed solids (\%) & 2.16 \\
\hline Volatile solids (\%) & 0.0769 \\
\hline
\end{tabular}

The $\mathrm{pH}$ (in water) of the waste sample was 5.57, which can be considered as being of a medium acidity. The sample presented a value of a cation exchange capacity (CEC) of $9.04 \mathrm{meq} / 100 \mathrm{~g}$ within the CEC range of kaolinitic clays ( 3 - 15 meq/100 g) [22], corroborating the kaolinitic character of the investigated waterworks waste.

It was also found that the waterworks waste presented a high organic matter content (24.3\%). This result suggested that the organic matter significantly contributed to the high value of loss on ignition. The waste sample presented real density of $2.27 \mathrm{~g} \mathrm{~cm}^{-3}$, which reflected its mineralogical composition. The surface area of water treatment plant sludge was $106.9 \mathrm{~m}^{2} \mathrm{~g}^{-1}$ indicating a porous material.

Water treatment plant sludge was characterized by the following granulometric composition: a sand fraction, $58.2 \%$ (particles with diameters between 0.06 and 2.0 $\mathrm{mm}$ ); a silt fraction, $6.83 \%$ (particles with diameters between 0.002 and $0.06 \mathrm{~mm}$ ); and a clay fraction, $35.2 \%$ (particles with diameter lower than $0.002 \mathrm{~mm}$ ).

Figure 2 shows the scanning electron micrograph of SWTP. As shown by the result of the SEM analysis, the sludge has irregular shapes which are probably flakes of fine kaolinite clay particles [23]. In addition, a wide particle size range can be observed, in accordance with the particle size data.

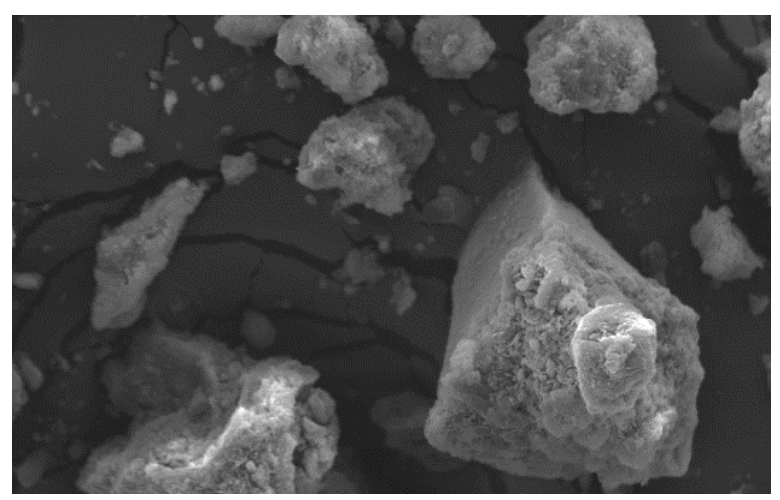

Figure 2. Morphology of the waterworks waste particles

The TG and DTG curves for the $10^{\circ} \mathrm{C} \mathrm{min}^{-1}$ heating rate under a $\mathrm{N}_{2}$ atmosphere are shown in Figure 3. The profile of SWTP weight loss exhibited three stages during the degradation process (Figure 3 ). The first occurred rapidly between 30 and $202{ }^{\circ} \mathrm{C}$ with loss of mass of around $12 \%$, while the second occurred between 202 and $397{ }^{\circ} \mathrm{C}$ with mass loss of $8.4 \%$. Finally, the third stage occurred between 399 and $906{ }^{\circ} \mathrm{C}$ with mass loss of $9.9 \%$. The remaining solid residue was $68 \%$ of the original mass.

The thermal events observed on the DTG curve are according to mass losses evidenced on the TG curve. The event which occurred at $76.1^{\circ} \mathrm{C}$ ( $\mathrm{T}$ peak) was the major reaction area and represents the elimination of free water between the particles. The $\mathrm{T}$ peak $=275.2^{\circ} \mathrm{C}$ is probably related to water loss from hydroxides and to the combustion of organic matter. The $\mathrm{T}$ peak $=490.9^{\circ} \mathrm{C}$ is attributed to the dissociation of constitution water (or structural water), i.e., comprising the hydroxyl group of the kaolinite clay mineral.

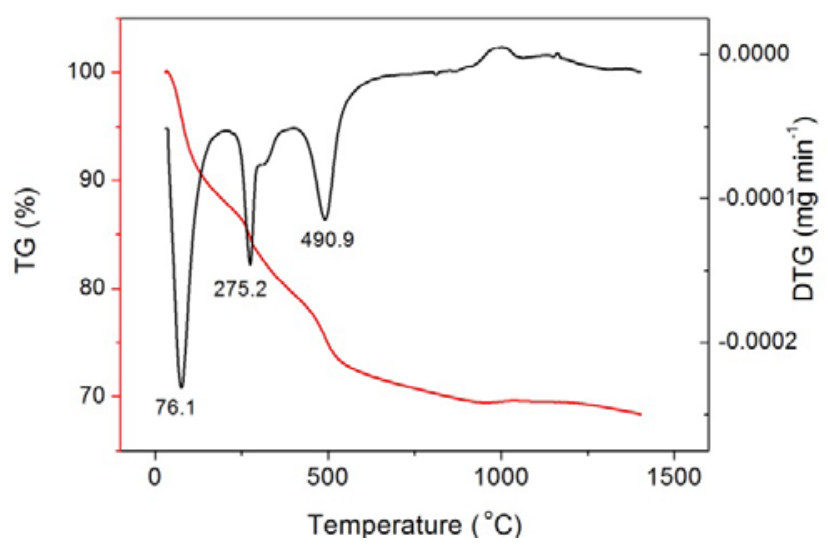

Figure 3. TG and DTG curves of waterworks waste 
Figure 4 shows the FTIR spectrum for SWTP. The FTIR spectrum of the raw sludge showed the presence of kaolinite, quartz, goethite and muscovite identified by XDR (Figure 1) and some organic matter. The assignments for FTIR spectrum has been reported elsewhere [24]. The SWTP sample had an FTIR spectrum consistent with previous reports in the literature [25].

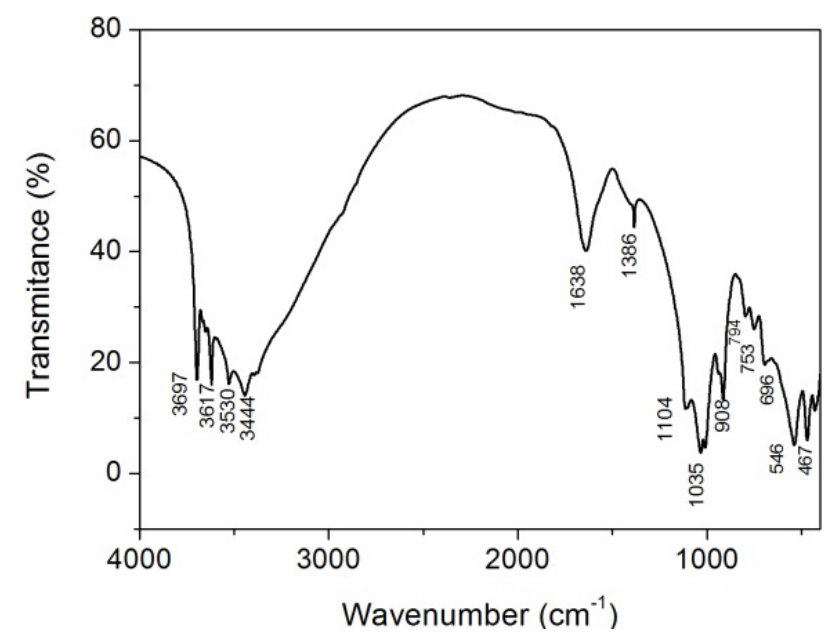

Figure 4. FTIR spectra of waterworks waste

\subsection{Characterization of CFA}

The XRD analysis of CFA powder revealed the presence of quartz crystallite and mullite as a major component of ash and some amounts of hematite, anhydrite and albite. The presence of amorphous phases are identified as a broad diffraction 'hump' in the region between 18 to 30 degrees $2 \theta$ (Figure 5). The intensity of quartz is very strong, with mullite forming a chemically stable and dense glassy surface layer.

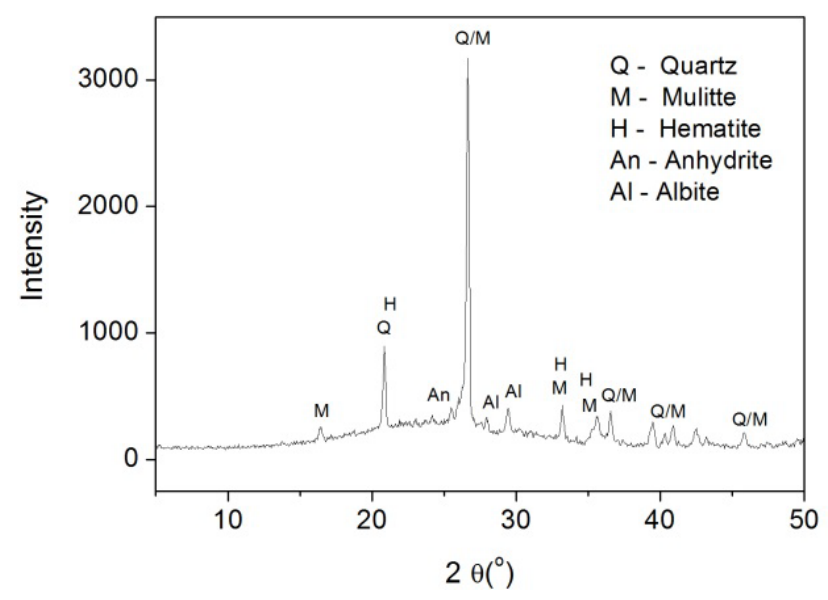

Figure 5. X-ray diffraction pattern of cyclone fly ash

The sample of coal fly ash collected by the cyclone from Figueira Power Plant was characterized and some physico-chemical characteristics of this material are shown in Table 4. The chemical composition of CFA sample reveals that the major components are $\mathrm{SiO}_{2}, \mathrm{Al}_{2} \mathrm{O}_{3}$, and $\mathrm{Fe}_{2} \mathrm{O}_{3}$. Some minor components like $\mathrm{Fe}_{2} \mathrm{O}_{3}, \mathrm{SO}_{3}, \mathrm{CaO}$, $\mathrm{K}_{2} \mathrm{O}$ and trace elements $(<1.2 \mathrm{wt} \%)$ are also present in CFA sample. The characteristics of Brazilian coal fly ashes have been previously discussed in the literature [14].

The FTIR spectrum of CFA is shown in Figure 6. The band at $3433 \mathrm{~cm}^{-1}$ is attributed to the asymmetric and symmetric stretching vibrations $v(\mathrm{O}-\mathrm{H})$, suggesting the presence of an amorphous silicate material (glass) or possibly hydrated aluminum silicates. The band at 1622 $\mathrm{cm}^{-1}$ is attributed to the bending mode of $\mathrm{H}_{2} \mathrm{O}$ molecules. A broad band at $1069 \mathrm{~cm}^{-1}$ is due to $\mathrm{Si}-\mathrm{O}-\mathrm{Si}$ asymmetric stretching vibrations of silica. The bands at 794 and 460 $\mathrm{cm}^{-1}$ could be assigned to quartz and silica, respectively.

Table 4. Physicochemical properties of cyclone fly ash

\begin{tabular}{|l|l|}
\hline Characteristics & Obtained Values \\
\hline Humidity (\%) & 85.0 \\
\hline Loss on ignition (\%) & 52.0 \\
\hline pH in water & 5.57 \\
\hline CEC ( meq.100 $\mathrm{g}^{-1}$ ) & 9.34 \\
\hline Organic matter content & 24.3 \\
\hline Apparent density $\left(\mathrm{g} \mathrm{cm}^{-3}\right)$ & 1.75 \\
\hline True density (g cm $\left.{ }^{-3}\right)$ & 2.27 \\
\hline Specific surface area $\left(\mathrm{m}^{2} \mathrm{~g}^{-1}\right)$ & 106.9 \\
\hline Total solids (\%) & 9.85 \\
\hline Fixed solids (\%) & 2.16 \\
\hline Volatile solids (\%) & 0.0769 \\
\hline
\end{tabular}

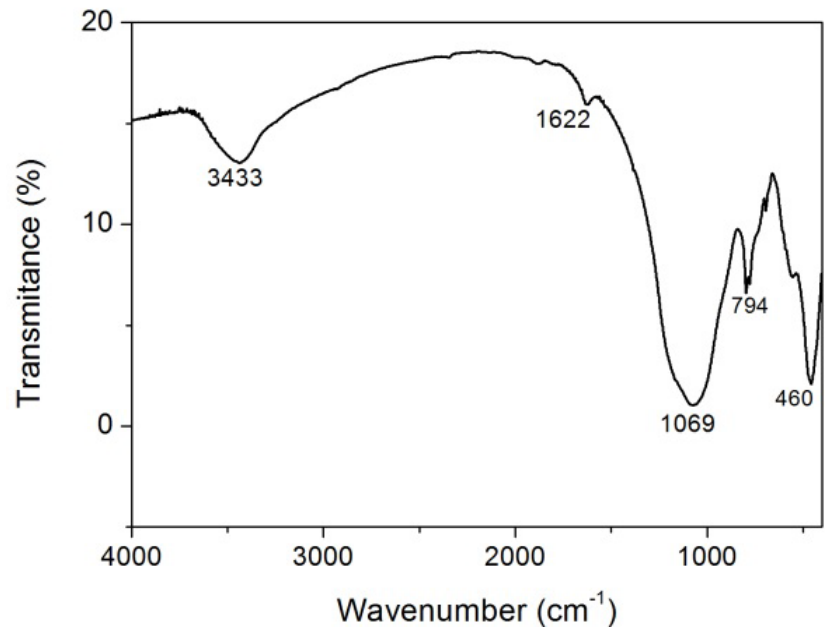

Figure 6. FTIR spectra of cyclone fly ash

Laser granulometric analysis results for CFA are reported both as absolute and cumulative volumetric distributions (Figure 7). From the cumulative distributions, the following values for $\mathrm{d} 10, \mathrm{~d} 50$ and $\mathrm{d} 90$ can be observed: 4.994, 15.575 and $52.526 \mu \mathrm{m}$, respectively.

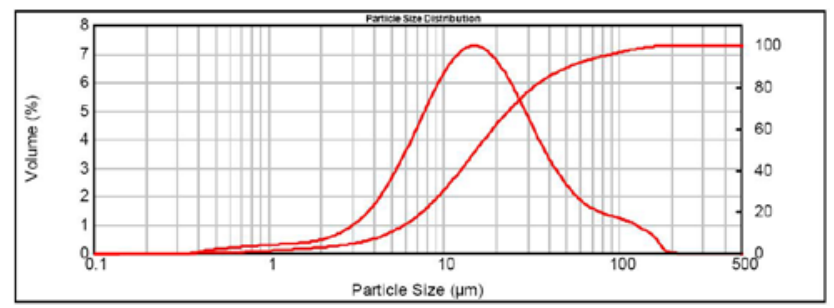

Figure 7. Particle size distribution of cyclone fly ash

The SEM image of CFA demonstrates particles of different shapes and sizes, which majority consisted of solid spheres (Figure 8A). Different physical states of silica are responsible for the particles of irregular size. Hollow microspheres (cenospheres), plerospheres (smaller spheres inside big sphere) and irregularly shaped 
unburned carbon particles tended to be in the upper end of the size distribution (Figure 8B).
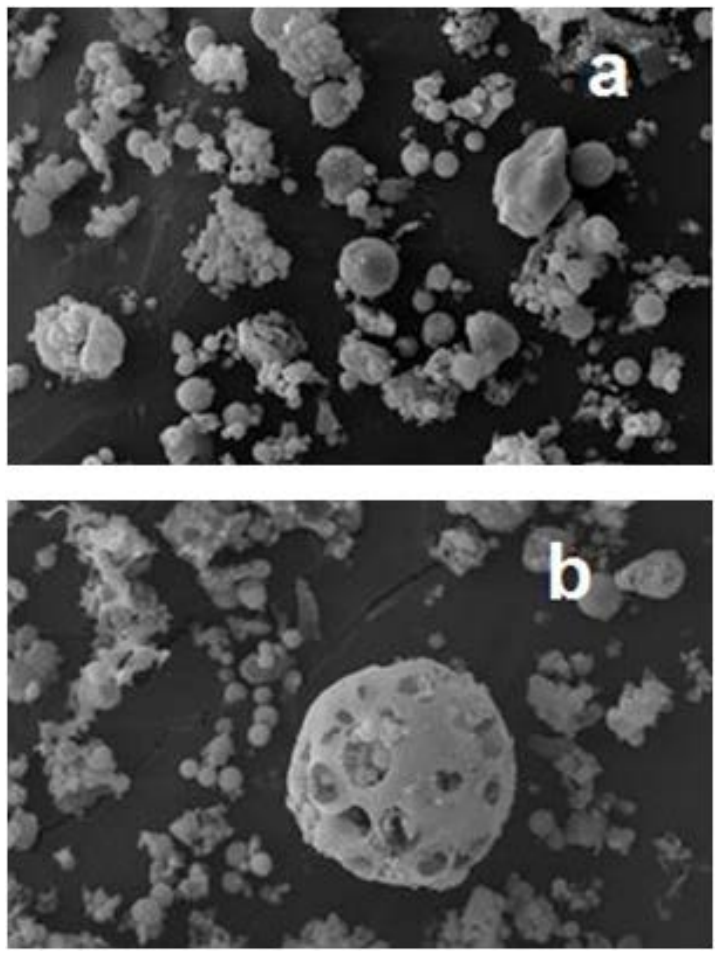

Figure 8. SEM micrographs of cyclone fly ash (a) particles of irregular size and spherical morphology; (b) hollow sphere (plerosphere) containing smaller hollow and empty spheres (cenospheres)

\subsection{Characterization of Bricks}

In this study, sludge of the treatment water plant stations (SWTP) and coal fly ash (CFA) were used for the manufacture of soil-cement and soil-lime bricks. The quality of the bricks after curing for 28 days was determined on the basis of compressive strength and water absorption. According to NBR standard 10836 [19], water absorption and compressive strength are properties that define the soil-cement brick quality after curing. The specified values for water absorption and compressive strength are $\leq 20 \%$ and $>2 \mathrm{MPa}$, respectively.

The compressive strength of the bricks is shown in Table 5. The brick pieces with 0 wt. \% wastes (sample BW0, $100 \%$ soil-cement body) were used as reference materials. As it can be observed, the compressive strength of the bricks presented decrement with wastes. Such a behavior is mainly related to the following factors: i) An inadequate granulometry of the SWTP; and ii) A small amount of Portland cement or lime in relation to other components of bricks. The values of compressive strength of BW3 sample are in accordance with the limit values of the Brazilian specification used for industrial production of soil-cement bricks.

Table 5. Average resistance to compression and average absorption of water

\begin{tabular}{|l|l|l|}
\hline Group & Resistance to compression (MPa) & Absorption of water (\%) \\
\hline BW-0 & 4.4 & 14.7 \\
\hline BW-1 & 0.7 & - \\
\hline BW-2 & 1.6 & 22.7 \\
\hline BW-3 & 2.1 & 14.3 \\
\hline BW-4 & 2.0 & 20.4 \\
\hline BW-5 & 1.5 & 17.3 \\
\hline
\end{tabular}

Table 5 shows the water absorption of the bricks. Water absorption is related to the volume of the open pores (i.e., the pores that are connected with the specimen surface). In addition, water absorption is closely related to densification and the microstructures of the cementitious matrix. It can be observed that the reference bricks BW2, BW4 and BW5 showed higher water absorption values than the reference bricks (BW0 sample). This is related mainly to the presence of a high amount of clay minerals (kaolinite and illite/mica) and an organic matter in the waterworks waste sample that tends to influence the cement hydration reactions [11].

The results obtained from compression resistance tests, for the case of BW1 bricks showed unfavorable results. They presented the average values of resistance to compression less than 1.0 MPa. Therefore, they were disregarded and the study of water absorption only included mixtures showing a favorable behavior. For BW3 samples the values of water absorption are according to the NBR standard 10836 [19].

The brick appearance is another important parameter of brick quality. The BW3 samples were reddish brown color, free of surface stains, efflorescence (soluble salts), and defects (Figure 9).

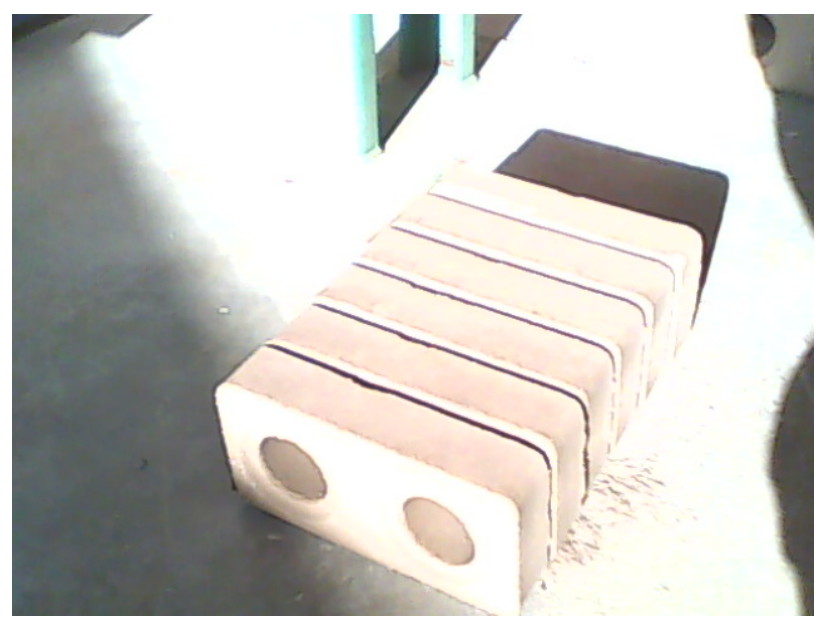

Figure 9. The appearance of the brick specimens (BW3 samples) after curing at 28 days

\section{Conclusion}

The results of this work have demonstrated that sludgecoal fly ash-soil-cement brick can be successfully produced using water treatment plant sludge and cyclone fly ash under the conditions and manufacturing methods used in this study. The proportion of sludge and fly ash in the mixture soil-cement and soil-lime was the two key factors affecting the quality of brick. The massive brick built with the composition of $60 \%$ soil, $12 \%$ cement, $8 \%$ coal fly ash and $20 \%$ water treatment plant sludge showed satisfactory results regarding to the mechanical and physical requirements (resistance to compression and absorption of water) stipulated by the Brazilian standards. This study showed that water treatment plant sludge and coal fly ash could be used as brick material for economic and environmental sustainability. The incorporation of these wastes into brick production is a suitable alternative to their current disposal paths. 


\section{Acknowledgement}

The authors are grateful to Conselho Nacional de Desenvolvimento Científico e Tecnológico (CNPq) and to Carbonífera do Cambuí (Figueira Power Plant) for providing coal fly ash samples for this study.

\section{References}

[1] Richter, C.A. Tratamento de Água: Tecnologia Atualizada, 2nd ed., São Paulo: Edgard Blücher, 1991.

[2] Davis, M.L., and Cornwell, D.A. Introduction to Environmental Engineering, 3rd ed., New York: McGraw-Hill, 1998.

[3] Di Bernardo, L., Dantas, A.D.B. Métodos e Técnicas de Tratamento de Água, 2nd ed., São Carlos: Rima, 2005.

[4] Teixeira, S.R.; Souza, N.R. Aléssio, G.T.A. "Efeito da adição de lodo de estação de tratamento de água (ETA) nas propriedades de material cerâmico estrutural”, Cerâmica, 52, 215-220, 2006.

[5] Prakhar, P.E., Arup, K.S. Donnan Membrane Process: Principles \& Application in Coagulant Recovery from Water Treatment Plant Residuals, Lehigh University, Bethlehem, PA, 1998.

[6] Mohammed, O. R, Hanan, A. F., Ahmed M. H. "Reuse of water treatment plant sludge in brick manufacturing”, Journal of Applied Sciences Research, 4, 1223-1229, 2008.

[7] Oliveira, E.M.S., Sampaio, V.G., Holanda, J.N.F. "Evaluation of the Suitability of Municipal Waterworks Waste as a Raw Material for Red Ceramic Brick Production”, Industrial Ceramics, 26, 2328, 2006.

[8] Oliveira, E.M.S., Sampaio, V.G., Holanda, J.N.F. "Effectof Waterworks Waste Addition on Densification and Properties of Clay Ceramics”, Industrial Ceramics, 27, 1-7, 2007.

[9] Porras, A.C., Isaac, R.L., Morita, D. "Incorporação doLodo de Estação de Tratamento de Água e Agregado Reciclado do Resíduo da Construção Civil em Elementosde Alvenaria - Tijolos Estabilizados com Cimento”, Ciência y Engenieria Neograndina 18, 5-28, 2008.

[10] SILVA, M.R. "Incorporação de Lodo e Estação de tratamento de Água (ETAs) em Tijolo de Solo-Cimento como Forma de Minimização de Impactos Ambientais,” Master Dissertation, Faculdade de Aracruz, E. S., 2009.

[11] Rodrigues, L.P., Holanda, J.N.F. "Characterization of Waterworks Waste for Use in Soil-Cement Bricks", Advances in Ceramic Science and Engineering (ACSE), 2, 135-140, 2013.
[12] Depoi, F.S.; Pozebon, D.; Kalkreuth, W.D. "Chemical characterization of feed coals and combustion-by-products from Brazilian power plants,” International Journal of Coal Geology, 76, 227-236, 2008.

[13] Quispe, D., Perez-Lopez, R., Silva, L. F., Nieto, J.M. “Changes in mobility of hazardous elements during coal combustion in Santa Catarina power plant (Brazil)”, Fuel, 94, 495-503, 2012.

[14] Fungaro, D. A.; Izidoro, J. C.; SANTOS, F. S.; WANG, S. Coal Fly Ash from Brazilian Power Plants: Chemical and Physical Properties and Leaching Characteristics, In: Fly Ash: Chemical Composition, Sources and Potential Environmental Impacts, Ed P. K. Sarker, Novapublishers, 2013.

[15] Shanthakumar, S., Singh, D.N., Phadke, R.C. "Flue gas conditioning for reducing suspended part culat e matter from thermal power stations," Progress in Energy and Combustion Science, 34, 685-695, 2008.

[16] Ahmaruzzaman, M. "A review on the utilization of fly ash", Progress in Energy and Combustion Science, 36, 327-363, 2010.

[17] ABNT, Brazilian Standard NBR 10832, "Manufacture of solid brick soil-cement with the use of manual presses," 1992.

[18] ABNT, Brazilian Standard NBR 10834, "Hollow Soil-cement block without structural function," 1994.

[19] ABNT, Brazilian Standard NBR 10836, "Soil-Cement Bricks: Determination of Compressive Strength and Water Absorption," 1994.

[20] Izidoro, J.C., Fungaro, D.A., Santos, F.S., WANG, S. "Characteristics of Brazilian coal fly ashes and their synthesized zeolites”, Fuel Processing Technology, 97, 38-44, 2012.

[21] Sotero-Santos, R.B., Rocha, O. and Povinelli, J., "Evaluation of water treatment sludge toxicity using the Daphnia bioassay," Water Research, 39, 3909-3917, 2005

[22] Santos, P.S. Clays Science and Technology, 2nd ed., São Paulo: Edgard Blücher, 1989.

[23] Haq, A., Iqbal, Y., Khan, M.R. "Phase and Microstructural Characterization of Kaolin Clays from North Western Pakistan," Journal of The Pakistan Materials Society, 3, 77-90, 2009.

[24] Tettamanti M, Lasagni M, Collina E, Sancassani M, Pitea D, Fermo P, Cariati F. "Thermal oxidation kinetics and mechanism of sludge from a wastewater treatment plant”, Environmental Science \& Technology, 35, 3981-3987, 2001.

[25] Awab, H., Paramalinggam, P.T.T., Yusof, A.R.M. "Characterization of Alum Sludge for Reuse and Disposal," Malaysian Journal of Fundamental \& Applied Sciences, 8, 209213, 2012. 